\title{
Greenlandic Language
}

National Cancer Institute

\section{Source}

National Cancer Institute. Greenlandic Language. NCI Thesaurus. Code C153968.

An Eskimo-Aleut language spoken by Greenlandic Inuit in Greenland. 